Western University Scholarship@Western

1991

\title{
The Antebellum American Tariff: Food Exports and Manufacturing
}

C Knick Harley

Follow this and additional works at: https://ir.lib.uwo.ca/economicsresrpt

Part of the Economics Commons

Citation of this paper:

Harley, C Knick. "The Antebellum American Tariff: Food Exports and Manufacturing." Department of Economics Research Reports, 9105. London, ON: Department of Economics, University of Western Ontario (1991). 
by

c. Kntck Harley

June 1991

\author{
Department of Economice \\ Soctal sctence Centre \\ Untverstty of Western Ontarto \\ London, Ontario, Canada
}

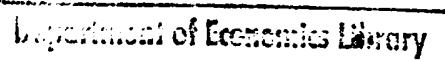

JUN 241991

Univorsity of Westom Ontario 


\title{
THE ANTEBELLUM AMERICAN TARIFF: \\ FOOD EXPORTS AND MANUFACTURING
}

\author{
by \\ C. Knick Harley \\ Department of Economics \\ University of Western Ontario \\ London, Canada N6A 5C2
}

June 1991

I would particularly like to thank Tom Rutherford for this assistance. Without his MPS/GE software this paper would have been impossible. Kim Scharf performed many of the calculations. John James graciously made detailed information of his model available to me. Earlier versions of this paper were presented to workshops at U.W.O., the University of British Columbia, Stanford, Berkeley, Davis, UCLA and Cal. Tech. I learned a great deal from the comments I received. Mark Thomas, Peter Lindert and Jeffrey Williamson made comments that have greatly improved the exposition. The financial support of the Social Science and Humanities Research Council of Canada (Research Grant \#410-87-1249) is gratefully acknowledged. 


\begin{abstract}
The American antebellum tariff provided high levels of protection to most of American manufacturing. Yet most economic historians have concluded that the tariff had modest effect on American industrialization in part because of terms of trade improvements arising from America's dominance as a raw cotton exporter. A computational general equilibrium analysis contradicts these conclusions. The tariff had no important terms of trade effects because America's marginal export was food not cotton. Furthermore, appropriate modelling of the competition between imports and domestic production shows that much of American manufacturing depended on tariff protection.
\end{abstract}


The United States is an enigma in the nineteenth century international economy; its image depends on the viewer's perspective. Sometimes the United States - the most important resource rich areas of new settlement - and Britain - the center of heavily populated, capital abundant Europe - represent the world economy. From this perspective, America industrialized unexpectedly, artificially stimulated by tariff protection. The more usual view American industrialization practically ignores the international economy; the tariff is usually mentioned and dismissed. Economic historians in the 1970s realized that analysis of the antebellum tariff required general equilibrium trade theory. Studies by Clayne Pope (1972, 1975), Ben Baack and Ed Ray (1973/4) and John James (1978, 1981) found that the tariff improved America's terms of trade by exploiting the South's market power in raw cotton and had little impact on the development of manufacturing. These results supported older views put forward particularly by F.W. Taussig and since endorsed by economic historians.'

New investigation, using recent improvements in applied general equilibrium analysis and far more realistic assumptions, shows that the Taussig-Pope-James conclusions on the antebellum tariff must be rejected. The tariff on manufactures failed to exploit the power the U. S. possessed in the world cotton market because the U. S. also exported food. In world food market the U. S. was unimportant and America's exports only a small part of output. With elastic supply and demand, food exports adjusted to the tariff and international prices were unaffected. The tariff stimulated American industrialization although the extent is hard to gauge. In the models the extent of stimulation depends on the willingness of American consumers to substitute imports for domestic manufactures. In a highly aggregated model with imports perfect substitutes for American goods, removal of the tariff eliminates manufacturing. But common sense and accumulated modelling experience show that perfect substitutability is inappropriate. With lower substitutability, the tariff has less effect. Data are too poor to support precise conclusions, but in 
plausible specifications much of American manufacturing depended on protection.

\section{Modelling the Mid-nineteenth Century Economy}

Tariffs, international trade and industrialization are inherently general equilibrium issues. John James $(1978,1981)$, made a pioneering contribution to early computational general equilibrium modelling by analyzing the antebellum tariff. Reexamination the antebellum tariff with techniques and experience now available reveals that two questionable specification features determined James' main results. The very sparse specification of the foreign sector, presumably adopted for computational convenience, generated the terms of trade results. This specification must be rejected on both analytical and historical grounds. An historically appropriate rest of the world eliminates James' terms of trade results, though the American economy retains market power in raw cotton that could have been captured by a cotton export tax. The willingness of consumers to substitute between domestic production and similar imported goods was James' second key assumption ${ }^{2}$ and determined the impact of the tariff on manufacturing output.

Competition between imports and domestic production requires more careful assessment than James' provided.

Reexamination of the antebellum tariff rejects the view that it had important terms of trade effects and only modestly aided American industrialization. The conclusions derive from changing the specification of key parts of the model not from new data or new equilibrium concepts. James' data has been almost totally retained and, although calculated by a different algorithm ${ }^{3}$, the equilibrium concept is unchanged. As much as possible of James' model has been retained.

James created a benchmark, assumed to be an equilibrium, from quantities and 
prices extracted from the 1859 Census (with modest adjustments for simplicity). Industries maximize profits; CES functions represent technology. Consumers own factors and maximize CES utility functions. Examination of alternate tariff policies and parameter values involves calculating new market clearing equilibrium prices and quantities.

James provided a rich sectoral structure for the United States. Seven sectors produce six goods: cotton textiles (which use cotton as an intermediate input), other manufacturing, labor intensive services, capital intensive services, raw cotton, and food (produced in a free sector and a slave sector). Representative consumers own each factor of production (land, capital, free labor and slaves) and maximize utility functions (consuming domestic and foreign cotton textiles and manufacture, both services and food). The government levies tariffs on imports -- twenty percent on manufactures and twenty four percent on cotton textiles -- and redistributes the proceeds to consumers in proportion to their benchmark income. Census data by state provided a basis for estimating production functions parameters. Other parameters were plausible assumptions. James closed the model with a sparse representation of the rest of the world. Here there are only two producing sectors -- cotton textiles that uses American cotton as an input, and foreign other manufactures. The rest of the world exports cotton textiles and other manufactures in return for American food and raw cotton. The representative foreigner consumes foreign cotton textiles, foreign manufactures and imported food. Table 1 reproduces James' summary of his model.

James found that eliminating the late 1850 s tariff caused a near twenty percent deterioration of the terms of trade and a fall in equilibrium American aggregate real income of just over one percent. Without the tariff raw cotton production was 4 percent higher and its price rose 7 percent. Slave owners benefitted from an 11 percent rise in slave prices. Land owners gained marginally. Small percentage losses to large aggregates of labor and capital more than offset these gains $(1978$, p. 248). The tariff had little 
impact (less than 2.5 percent) on the output of U. S. cotton textiles and other manufacturing. James calculated the optimal tariff to be the neighborhood of thirty five or 40 percent (1981, p. 731). This high optimal tariff reflected the large effects of tariffs on terms of trade.

I have recalculated James' model (Case A) with only slight changes and reproduced many results, at least qualitatively, but some conclusions did not emerge. Before repeating James' simulations I made a few slight modifications. U. S. exports seem better represented by $\$ 70.1$ millions food and $\$ 190.1$ millions cotton, which approximate the final three antebellum years, than by James' $\$ 85$ millions and $\$ 175.2$, which reflect special conditions of 1860 . Some other unimportant differences may have arisen from ambiguity in James' description. The effect of removing the tariff, although somewhat different in detail, qualitatively reproduces James' results. ${ }^{4}$ On the other hand, simulating high tariff to find optimal tariff did not reproduce James' result. Instead, reestimation (James in Figure 1) shows smooth increases in welfare as tariffs increase at all tariff rates investigated (up to 400 percent); a result that derives from the rest of the world's complete dependence on American for raw cotton and food.'

\section{The Rest of the World, American Food Exports and Terms of Trade}

James' main results arose from two features of his model. The specification of the rest of the world generated the tariff's improvement of the terms of trade. With an historically more appropriate the rest of the world terms of trade effects disappear. The size of production and welfare changes depend on precise specification of American consumers' willingness to substitute imports for similar domestically produced goods but the tariff has little terms of trade effect and reduces welfare regardless of substitutability. Substitutability, although not irrelevant for terms of trade, mainly effects the impact of the 
tariff on the manufacturing sector and will be discussed below in section III.

\section{A. James' Rest of the World, Food Exports and Terms of Trade}

James' rest of the world bears little resemblance to the large, complex world economy that traded with the United States in the 1850s. It produced only cotton textiles and other manufactured goods and generated some 15 percent less income than the United States. Foreigners depended on America for both raw cotton and food. As will become apparent, the modeled dependence on American food is particularly troublesome. In fact, of course, U. S. food supplies were marginal, even for Britain, by far the world's largest food importer. Britain produced some two thirds of the agricultural goods it consumed and most of its imports came from Europe. Conservative estimates of the relevant world food consumption based on European population suggests that U. S. exports were only about half a percent of consumption of the rest of the world.

James structured his model to limit complexity but modelling the rest of the world without food production had the unintended effect of greatly reduced the elasticity of the foreign offer curve and increased the effect of the tariff on the terms of trade. As is well-known, the elasticity of the offer curve depends on the responsiveness of both production and consumption. Realistically allowing foreign food production increases import demand elasticity; a higher international price of food induces both increased domestic food production and a decline in consumption.

James' results reveal the unfortunate impact of modelling the rest of the world as dependent on American food. His intention was to examine America's "monopoly power internationally due to its position as the major producer of raw cotton," (1978, p. 232) and he talked about the tariff raising the international price of cotton. But his results show that most of the terms of trade effect came from the rise in the international price of food. Tariff removal resulted in the changes in international prices and traded quantities traded food, raw cotton, cotton textiles and other manufactures shown in Table 
2. American consumers substituted imports for domestic manufactured goods and the American economy adjusted to generate exports to pay for them. In the optimum tariff story these exports are raw cotton' whose price must fall because America is the dominant supplier and demand is inelastic. In the simulation, raw cotton exports increase, but increased food exports provide most of the adjustment. Raw cotton exports increase by 7 percent and prices fall 6 percent relative to rest of the world manufacturing prices but food exports increase by 38 percent ( 2.5 times as much as cotton in benchmark prices) while prices fell by 12 percent. Most of the terms of trade improvement came not from America's market power in raw cotton but from the model's presumably unintended market power in food.

B. Historically Appropriate Specification of the Rest of the World

Although a small foreign sector was computationally convenient, it inappropriately determined results. European data provides the basis for a still simple but much more realistic alternative (Case B, in Table 3$)^{8}$. The economy is diversified and larger -- some seven times the size of the United States. The U. S. supplies an appropriately modest part of the rest of the world's food. A larger manufacturing sector allows for industry outside Britain. A substantial non-traded sector is included.

America's food exports consisted mainly of simple homogeneous products that traded on well organized markets. Wheat and flour, amounted to some two fifths of America's non-cotton agricultural exports, and were already integrated into a global commodity market (Harley, 1980). Packing-house products -- almost entirely low quality salted beef and pork, tallow and lard -- were about half as important as wheat and were also homogeneous internationally traded commodities. These commodities were the margin at which American food exports increased and shrank in the mid century decades. The Crimean War in the mid 1850s disrupted Russian wheat and tallow supplies and Americans exported about twice as much wheat and packing house products exports as in 
the late 1850s. During the Civil War exports were even larger, about four times the levels of the late antebellum benchmark. By the early 1870 they had grown to twice their Civil War peaks -- about eight times benchmark levels. These increases in American exports were absorbed seamlessly into European markets. It seems appropriate for the model to assume that the quantity of U.S. exports did not affect the price of American food relative to the price of food produced elsewhere.9

\section{Simulation: the Absence of Important Terms of Trade Effects}

With an historically appropriate rest of the world, simulations of tariff removal yield no important terms of trade effects. This is a robust conclusion, that survives sensitivity experiments. The lower panel of Table 2 compares the effect of removing the tariff with James' structure and with the rest of the world remodelled (Case B, Big R. o. W.). The American tariff makes practically no difference to international prices, food exports expand considerably more than with James' specification and cotton exports grow somewhat less. Because the foreign manufactured goods do not become more expensive, America imports more than under James' specification.

Intuition on the antebellum tariff needs revision. Consider the economics driving these results. In James' model the demand for food, as well as for raw cotton, is inelastic and so it resembles the simple two-good optimal-tariff case. Foreign buyers increase purchases of both cotton and food only when their prices fall.

Recognition of America's position as a marginal supplier of food to the rest of the world fundamentally alters the model. Equilibrium is easily restored with only minor changes in international price ratios because international demand for American food is elastic and large increases in sales and revenue result from an imperceptible fall in price. In the simulation, removal of the tariff increases the relative price of raw cotton slightly by increasing the world consumption of cotton textiles. The simulated change in food exports -- more than doubling -- seems large, but is only six percent of American production and 
half a percent of the rest of the world's consumption. It approximately equals the increase in the mid 1850 s and is much smaller than those in the 1860 s and 1870 s. It is hardly surprising that such adjustments could be made with almost no changes in relative prices. ${ }^{10}$

The United States possessed market power in raw cotton but the tariff could not exploit it because America also exported food as a marginal supplier. Food was the export that adjusted to equilibrate the balance of payments when the tariff changed. As a result the tariff lacked terms of trade effects, reduced food exports and diverted resources from agriculture. The tariff reduced American welfare. Losses fell on food, land-owners and the West as well as on cotton and Southern slave holders, while regions and factors that specialized in manufacture benefitted. Changes in production and trade quantities, factor prices and welfare from tariff removal depend on consumers' willingness to substitute between imports and domestic manufactures -- an issue yet to be discussed. The production, distributional and total welfare impact of tariff removal varies from slight when imports and domestic production are poor substitutes to considerable when imports and domestic production are perfect substitutes. Table 4 presents values of key variables at free trade equilibrium with various specifications that are discussed below (see Table 3). Cases I - IV represent the plausible parameter range; Cases A - C illustrate results at extreme parameter specification.

\section{Optimal Export Tax}

Food exports prevented the American tariff from exploiting the market power inherent in the South's dominance in raw cotton production. That power could, however, have been exploited by an export tax. The option was never seriously considered because it had been explicitly prohibited in the U.S. Constitution (Section 1, Article 9.5). The South, of course, was even more opposed to an export tax than to the tariffs because it was so clearly tax on its regional product.

Exploration of the optimal export tax, and the welfare effects of high American 
tariff rates", requires incorporating additional realism into the modeled rest of the world. In James' model, only the United States grew raw cotton. Also, cotton textiles and other manufactures were poor substitutes in rest of the world's consumption. To confine cotton production to the United States and to limit the substitution possibilities between cotton and other manufactured goods is historically inappropriate. Without modifications foreign demand for raw cotton remains inelastic at all relative prices so the United States would always benefit from increasing a cotton export tax.

The United States produced nearly all the world's raw cotton, but others did grow about a fifth of the total. During the Civil War, production outside America increased rapidly despite expectations that American supply would resume when hostilities ended. British cotton prices quadrupled and supply from non-U.S. sources more than doubled (Ellison, 1886, pp. 86-94). Appropriate modelling of the rest of the world needs to incorporated that supply response. This has been done by modelling the rest of the world's agriculture as producing food and cotton jointly with an elasticity of transformation from food to cotton of 0.8 .

The willingness of consumers to substitute other goods, particularly traditional textiles, for cotton textiles as American export taxes drive up the price is a second key determinant of the elasticity of demand for raw cotton. Early nineteenth century British experience provides evidence to calculate the size of this response. British cotton textile output grew spectacularly during the early nineteenth century as consumers switched from traditional textiles to cheapening cottons. Between 1815 and 1841, the price of cottons fell some fifty percent relative to other manufactured goods and relative quantity increased nearly three and a half fold (Harley, 1982). The model of the rest of the world incorporated this behavior with an elasticity of substitution 1.5 between cotton textiles and other manufactures.

The model now incorporates important features of the early nineteenth century 
that James' ignored and can explore high tariff rates and cotton export taxes (see Figures 1 and 2). Increasing the tariff at low rates reduces American welfare, as we have seen from comparing the 1860 tariff with free trade. At low tariff rates, increasing the tariff contracts food exports. Eventually American food exports become eliminated (at about a 30 percent tariff -- the low points in Figure 1). Then traditional optimal tariff considerations operate and increasing the tariff improves American welfare. Foreign production of raw cotton and substitution of traditional manufactures for cotton textiles eventually cuts off welfare improvement and American welfare declines as tariffs increase at very high rates. In none of the simulations do the eventual gains from exploiting cotton market power offset the inefficiency involved in reducing the exchange of food for manufactured goods.

A cotton export tax would have avoided the tariff's effect on food exports and exploited America's market power in cotton (Figure 2). The optimal cotton export taxes appear to be about 60 percent. $^{12}$ Here, as elsewhere, precise magnitude of the gains depends on the specification of American import demand. Welfare gain with an optimal tax exceed free trade welfare by about one percent. Compared to the actual tariff policy gains are larger -- about three percent at maximum. As expected, although aggregate utility is increased slave owners suffer.

\section{Industrialization and the Tariff}

The antebellum tariff was highly protective and designed to stimulate manufacturing (Figure 3). Cotton textiles were particularly heavily protected; ${ }^{13}$ rates exceeded 100 percent (double that rate on value added since raw cotton amounted to half the cost of cotton cloth) in the tariff of 1842 . Despite the height of the tariff, most economic historians have followed Taussig, recognizing the stimulus of the early tariff but arguing 
that by the second quarter of the century most manufacturing did not require support. James' results supported that view: simulating tariff removal only trivially reduced American manufacturing. Improvement in the terms of trade reduced the impact of tariff removal but the small reduction in domestic production arose mainly from modelling imports and domestic production as poor substitutes. James assumed the key substitution parameter without examining its implications. In effect he assumed that the tariff had little impact on manufacturing. Examination of the vulnerability of American manufacturing to imports and sensitivity experiments with different plausible specifications shows, in contrast to James' results, that with no tariff the American manufacturing sector would have grown more slowly and Western agriculture would have grown faster.

\section{A. Demand Specification: Imports vs. Domestic Production}

In James' model (and models derived from it) effects of the tariffs overwhelmingly reflect the assumed substitutability in demand between imports and domestic production. With James' limited substitutability, tariff removal hardly affected manufacturing (Case B, Table 4). Imports became 20 percent cheeper but hardly increase market share. At the other extreme where domestic production and imports are modelled as perfect substitutes (Case C), tariff removal, in contrast, eliminates both American cotton textiles and other manufacturing.

Modelling the competition between imports and domestic production is an incompletely resolved issue in empirical general equilibrium analysis. Perfect substitution between imports and domestic production usually generates unrealistically extreme specialization (Dervis, et. al., 1982, pp. 219-221). Imperfect substitution, reflecting the heterogeneous goods aggregated into the model few goods, seems appropriate. The usual modelling strategy, followed by James, is to adopt the so-called Armington framework. The Armington utility function models the import good and its domestic counterpart as imperfect substitutes that are aggregated with a relatively high elasticity of substitution into 
a composite good. Composite goods enter a higher level utility function that has lower substitability (Dervis, et. al., 1982, pp. 221-224; Shoven and Whalley, 1984, pp. 1017, 1034 and 1042).

The Armington approach is appropriate to manufacturing in late antebellum America. The manufacturing aggregate consisted of industries producing a wide range of goods differently subject to international competition. Raw material processing -grain-milling and saw-milling, in particular -- was unaffected by foreign competition. Local fabrication that was only imperfectly traded also made up much of the sector. Cotton textiles, in contrast, produced much more homogeneous output. Yet even here a range of fabrics existed and American manufacturers were more competitive in coarser goods. A higher elasticity of substitution is appropriate for cotton than for other manufacturing.

The Armington aggregation elasticities are crucial but unknown. A partial solution is to simulate a range of plausible values. In James' model consumers' preferences are nested CES utility functions in which the broad category, "cotton textiles," is a CES subaggregate of foreign and domestic cotton textiles. As James pointed out (1979, p. 242) "(1)ack of appropriate data. . .prevents direct estimation of the parameters of the utility functions, so they must be imposed." He assumed the elasticity of substitution among broad categories of goods to be below 1 but to increase with average income; simulations retain his selection. For the crucial elasticities of substitution between imported and domestic goods he assumed a value of $2.0(1979$, p. 243$)$ "since . . .domestic items and imports were substitutes but not extremely close ones."

The elasticity of 2 here represents very limited substitution. The relationship between substitution elasticities and the response of domestic output is shown in Table 5 . The shares of domestic production and imports at the benchmark antebellum equilibrium are compared with calculations of shares when import price fall relative to the domestic price by the amount of the tariff ( $24 \%$ on cotton textiles and $20 \%$ on manufactured 
goods). With an elasticity of substitution of 2 , the sharp fall in the relative price of imports increased import shares only trivially. Even with an elasticity of substitution of 10 , domestic production retains a large share despite its relative price rises. ${ }^{14}$ B. The Dependence of Domestic Production on Protection

Various evidence provides hints about the viability of American manufacturing without a tariff. American textiles and primary metals depended heavily on the tariff. Raw material processing industries certainly did not. Other industries, such as machine making, which provided services with products to their customers were more ambiguously placed.

\section{i. Cotton Textiles ${ }^{15}$}

The American cotton industry grew rapidly behind prohibitive tariffs but many commentators (Copeland, 1917, Stettler, 1970, Zevin, 1972) have accepted Taussig's judgement that the industry could have withstood tariff removal by the 1830 s. Recent research (Bils, 1984, Temin, 1988, Harley, 1992), however, has challenged this view.

Different kinds of textiles were differentially dependent on protection. America did best in low cost, coarse textiles that took advantage of America's cheaper raw cotton and water power. Some of cotton goods were produced efficiently enough to export. In the late 1850 s, American firms exported about $\$ 4$ million dollars worth of coarse cotton cloth to South America, the West Indies, China and India. The export success should not be overestimated. Americans imported nearly $\$ 17$ million of British cotton cloth and would undoubtedly have imported much more without the tariff. Canada (Table 6) may provide an approximation of the American market without the tariff. The Canadian social and physical environment resembled the mid-western United States; British and American products faced the same 15 percent tariff; and commercial connections to both countries were roughly equivalent. American cotton firms supplied less than ten percent of the Canadian market. 
Comparison of textile prices in Britain and America shows that tariff removal would have threatened even coarse American cotton textiles (Harley, 1992). Only American products that sold in the competitive domestic market at or below the British price plus transportation would have survived. Both American standard printing cloth and heavy "domestic" cloths -- the American specialty -- sold at prices well above similar British products plus transportation. Some American "domestic" cloth was being exported and did not need the protection of the tariff but removal of the tariff would have put heavy pressure on most the industry. This evidence and the elasticity results in Table 5 suggest that the appropriate elasticity of substitution in the Armington cotton textile sub-aggregate was at least $10 .^{16}$

\section{ii. Other Manufacturing}

The range of activities encompassed in other manufacturing were, as the Canadian import data (Table 6) suggest, differential vulnerable. The other textiles depended on the tariff as much as cotton. Primary iron also depended on protection; only 10 percent of Canadian imports of the pig and basic manufactured iron came from American producers. Robert Allen's (1979, p. 921, Table 4 and p. 924, Table 5) detailed international comparison confirmed the vulnerability: American pig iron and rails cost nearly sixty percent more than British in the 1850s. ${ }^{17}$ Textiles and primary metals together constituted 22 percent of the value added in 1860 by other manufacturing (Niemi, 1974, p. 7). At the other extreme, the tariff did not affect food processing, tobacco, lumber and wood products, and stone, clay and glass, that made up 27 percent of value added.

Tariff removal would have affected the remaining half of manufacturing to various degrees. Canadian data show that the large leather and leather products sector (11 percent of manufacturing value added) was safe. Ninety five percent of Canada's imported boots and shoes came from the States (reflecting American technological leadership) although only half other leather manufactures did so. In hardware, Canada 
imported about equal amounts from Britain and the United States. Americans contributed some three quarters of machinery imports; removal of the tariff would have hurt American machinery makers mainly by reducing demand from tariff dependent customers. Overall a decline in manufacturing of between a third and a half from removal of the tariff seems appropriate. As Table 5 shows that this implies an Armington elasticity of at least 5 .

\section{B. Various Simulations: Substitution Elasticities and Factor Mobility}

The uncertainty and importance of the elasticity of substitution between imports and domestic production dictates exploration of a range of elasticities (see Table 3 for the specifications of the cases considered and Table 4 for results). Extreme cases are B with James' elasticity of 2 , which yields very little impact, and $C$ where domestic and foreign goods are prefect substitutes and tariff removal eliminates both domestic cotton textiles and other manufacturing. Description of adjustment to tariff removal in these cases highlights the role of the elasticities of substitution. With James' limited substitution, tariff removal reduces demand for domestic products only slightly. Excess supply is eliminated by reducing the size of the domestic industry, which occurs with only very small changes in relative prices in the domestic economy. In contrast if imports and domestic products are perfect substitutes, imports freed of duty initially capture the entire domestic market. American industry can survive only if transfering resources from the industry lowers cost of production by the amount of the tariff reduction -- modified by any terms of trade effects. In this classic Hechcksher-Ohlin case, previously protected industries continue to exist only if factor price movements lower their costs enough to offset the effect of tariff removal. The production possibility frontier in the model is flat because factors of production move without friction between sectors and manufacturing use no specific factors. ${ }^{18}$ As a result the manufacturing sectors in America disappear.

Discussion of adjustment shows the inappropriateness of both extreme specifications. Substitutability between imports and domestic production needs to be examined, 
particularly in the heterogeneous other manufacturing sector. In addition, modifications need to allow greater cost reductions as the industrial sectors shrink. Modification the model's assumption that factors of production can move freely between sectors increases the cost savings from industry contraction.

Discussion in the previous section suggests that substitution elasticities of 10 between imported and domestic cotton textiles and 5 in other manufacturing (Case I) is a somewhat conservative realistic specification (in the sense of small impact). Equilibrium without a tariff (Table 4) has textile output nearly 55 percent lower and imported textiles some 18 percent cheeper relative to domestic prices. Other manufacturing output declines by 17 percent in response to a 13 percent fall in relative import prices. Terms of trade between exports and imports improve by half a percent. In comparison to James' specification, the cotton textile industry is smaller because with higher Armington elasticity removal of the tariff causes a greater switch of consumption to imports. A greater reduction in the domestic industry's size is needed to restore equilibrium. Price adjustments remain very small.

At the high elasticity end of the plausible range foreign and domestic cotton textiles become perfect substitutes and an elasticity of substitution of 10 is used in other manufacturing (Case II). Tariff removal eliminates American cotton textiles because factor price changes in response to tariff reduction do no lower the industry's costs as much as removal of the duty reduces the costs of imports. Just over two thirds of other manufacturing remains because demand effects are much less for the heterogeneous sector.

In all the models discussed so far, a decline of less than one percent in the price of cotton textiles in America causes abandonment of the industry (other manufacturing is abandoned in response to only sightly greater price decline). This willingness to abandon whole sectors in response to small price changes arises from the unrealistically modeled free transfer of capital and labor among industries. Families and capital in antebellum 
America possessed regional and industrial attachment. A regional labor market and low wages, or downward pressure on wages, motivate discussions of New England's early industrialization (Field, 1978; Goldin and Sokoloff, 1982). Imperfect mobility can be most easily modeled by introducing a labor transformation sector that reallocates labor with less than infinite elasticity. The effect of tariff removal has been simulated with a constant elasticity of transformation of 5 between sectoral labor supplies (Cases III and IV).

Modelling the labor sector with imperfect mobility represents heterogeneity among loborers. Some leave declining sectors in response to a small fall in relative wages while others remain as relative wages deteriorate. Figure 5 illustrates the relationship between relative wages and labor remaining in the declining sector embodied in the elasticity of transformation of 5 . The median worker will leave the declining sector when relative wages have fallen thirteen percent and 80 percent will have gone when wages fall by a quarter.

Imperfect factors mobility and imperfect substitution between foreign and domestic commodities in demand together provide the best approximation to historical reality. Case III combines imperfect labor transformation with the elasticities of substitutions in consumption of 10 for cotton textiles and 5 for manufactured goods of Case I. The decline in textiles and manufacturing and most welfare changes are smaller. Imperfect labor mobility reduces quantity responses by increasing price effects. As the cotton textile and manufacturing sectors decline wages fall in those sectors and product prices fall. Lower prices stimulate demand and attenuate quantity declines. Sectoral wage changes introduces additional distributional effects within labor. ${ }^{19}$ Cotton wages fall about 9 percent compared to wages elsewhere and other manufactured wages about 4 percent.

Case IV, that combines limited factor mobility with the perfect substitutability in textiles and an elasticity of 10 in other manufactures of Case II, is perhaps the most attractive specification. Tariff removal leads to a virtual elimination of cotton textiles and 
a 22 percent decline in manufacturing accompanied by a six percent relative fall in manufacturing wages.

C. The Tariff, Industrialization, Agriculture and the West

The impact of the tariff on American industrialization depends on unknown willingness of Americans to buy imports in preference to domestic goods and on their willingness to move in response to falling wages. Our knowledge is too scant to permit precise estimates, but the very small impact that James' found seems an inappropriate result of his specification. If Cases III and IV that incorporate some factor immobility with higher substitutability in consumption are accepted as reasonable bounds of the likely results, tariff removal would have reduced American cotton textiles by at least a third and perhaps led to its disappearance while other manufacturing would have declined by a sixth to a quarter.

The tariff, of course, restrained export industries, mainly Western food production, while stimulating import competing textiles and other manufacturing. Three quarters of American antebellum exports were raw cotton and other agricultural goods providing the balance. Because the demand for raw cotton was inelastic and that for foodstuffs was not, the antebellum tariff mainly constrained the expansion of Western agriculture. It is tempting to see the tariff primarily as reducing land rents on a fixed area under cultivation, in the tradition of British classical economics. This intuition, although consistent with the formal models, is inappropriate to antebellum America. The margin of cultivation was extensive not intensive, and physically located on the frontier in the West. In Cases III and IV food production expands between 10 and 15 percent with tariff removal. Most expansion would have occurred as settlement on the western frontier. If say 80 percent of the growth occurred in the west, settlement there would have been 15 to 20 percent higher without the tariff. 


\section{Distribution}

Political debate on the antebellum tariff centered primarily on distribution. Aggregate impact of the tariffs on welfare was inevitably small; imports were only 6 percent of GNP and the average tariff only twenty percent. Tariff policy could, nonetheless, have had considerable effect on individual groups owning specific factors in specific regions. Antebellum political debate suggests many contemporaries felt that redistribution was substantial. Simulations produce distributional effects and provide insights into the politics of the tariff.

Estimates of the distributional effects of the tariff are presented in Table 7. Cases I and II, with perfectly mobile factors, provide straight forward factor incomes and utility indices for representative factor owners. But Cases III and IV, with imperfect mobility of labor probably better characterizes the antebellum economy and provides more reliable insight into the distributional features of the tariff. Calculation of the impact of tariff removal on sub-groupings of labor in these simulations is somewhat complex since the labor groups are not explicitly modeled. Imperfect labor mobility implies that some laborers leave declining sectors as soon as relative wages start to fall but others remain in spite of their deteriorating situation. Workers employed in sectors where tariff removal increases real wages gain the utility associated with their increase in real wages but workers in declining industries have diverse experiences depending on their willingness to move. Those who would move immediately a wage gap develops share the gains of workers in the gaining sectors. Those who would remain in the declining sector at lower wages suffer losses. Table 7 present average welfare change from tariff removal to workers in cotton, manufacturing and in non-protected sectors in the two simulations. Redistribution within the labor force is considerable with cotton workers suffering most. Labor and capital associate well with identifiable interests. Land and slave returns 
undoubtedly determined some individuals' fortunes, but farmers and planters with diversified factor holdings owned most land and slaves (see factor inputs into food and cotton production in Table 1). Farmers' interests were primarily in labor and land. Capital was an important farming input but its ownership is more difficult to assign since many farmers were debtors. The effect of tariff removal has been calculated for two types of farmers. The first owns his capital while the second rents capital. Planters also have a diversified portfolio: fifty eight percent of their wealth is slaves and the balance, land and capital.

Northern industrialists, with income primarily from capital, clearly gained from the tariff. The estimates of three to five percent recorded in Table 7 probably underestimates the gains for this group. Any unmodeled immobility of capital from manufacturing in New England and the Mid Atlantic states would increase the magnitude of these gains.

American capital was mobile, Eastern capital built most of the West's railroads, but regional interest differentials existed. The increase on the return to land approximated the returns to speculators in Western land. Those with large land holdings would have benefited most from tariff removal. Of course, the federal government originally held unsettled western land and most private owners got their holdings with the tariff in place. Two important groups, western farmers and southern planters, had combined factor incomes. Western farmers would have benefitted from tariff removal, considerably more if they borrowed capital than if they owned it. The southern planter, with their wealth primarily in slaves and land would have gained noticeably from tariff removal. Debtors would have benefitted more than the non-debtors.

Aggregating into larger groups reduces distributional effects since larger groupings contain gainers and losers. In regional aggregates of non-farm labor, for example, small gains by the large amount of labor in services in the Eastern states almost completely offsets the losses to cotton textile and manufacturing labor. There is a small interregional 
aggregate effect. Its exact magnitude depends on the ownership of capital in various regions. Easterners owned considerable Western capital, particularly in transportation. Since capital would have been a major loser from tariff removal, accounting for this differential capital ownership would increase the regional redistribution. Table 7 includes calculations with all western capital owned in the west and with half of western capital owned in the east.

\section{Conclusions}

Views of the tariff that emphasize American market power in raw cotton production are misleading. Specific details remain uncertain but several conclusions may be accepted with confidence. First, the antebellum tariff did not exploit the United States' dominant position in raw cotton because food was the marginal export. Second, protection increased the size of the American manufacturing sector and particularly the cotton textile industry. Third, despite small overall welfare costs of the tariff, distributional effects, with political implications, were considerable.

The manufacturing tariff did not exploit United States' market power as the dominant raw cotton producer. The marginal American export was food and not cotton. In the world food market the U. S. was a minor supplier, so at the margin U. S. exports faced elastic demand. The tariff reduced American imports and in turn reduced the export of foodstuffs. The main costs of the tariff thus fell on land, as the factor used intensively in food production. The West as well as the South were the principal losers from the protection of manufacturing.

Historians have minimized the effect of the tariff on the size of the American manufacturing sector. There is little actual evidence supporting this position. Taussig's conclusion holds only if imports were very poor substitutes for U. S. production. A range 
of plausible specifications reveals considerable tariff impact. Tariff removal would have reduced the American cotton textile industry by a third and probably considerably more. The effect of the tariff on other manufacturing harder to decide; it was less, probably about half the effect on cotton textiles.

The protected sector of the American economy was small in the antebellum years and the tariff rates were moderate so the aggregate welfare loss was probably much less than one percent of national income. The aggregate masks distribution effects. Removal of the tariff might plausibly have made the average cotton textile laborer some fifteen percent worse off while making western debtor farmers nearly ten percent better off. Other manufacturing labor would have lost noticeably but less than cotton textile workers. Capitalists would have suffered losses. Planters would have had noticeable gains and land speculators, very significant gains. These distribution effects are in line with informed contemporary opinion although the impact on the West may have been only partially perceived. They fit well with the political debate in antebellum America. 
Table 1

James' Model Specification

A. Parameter Specification for the Model:

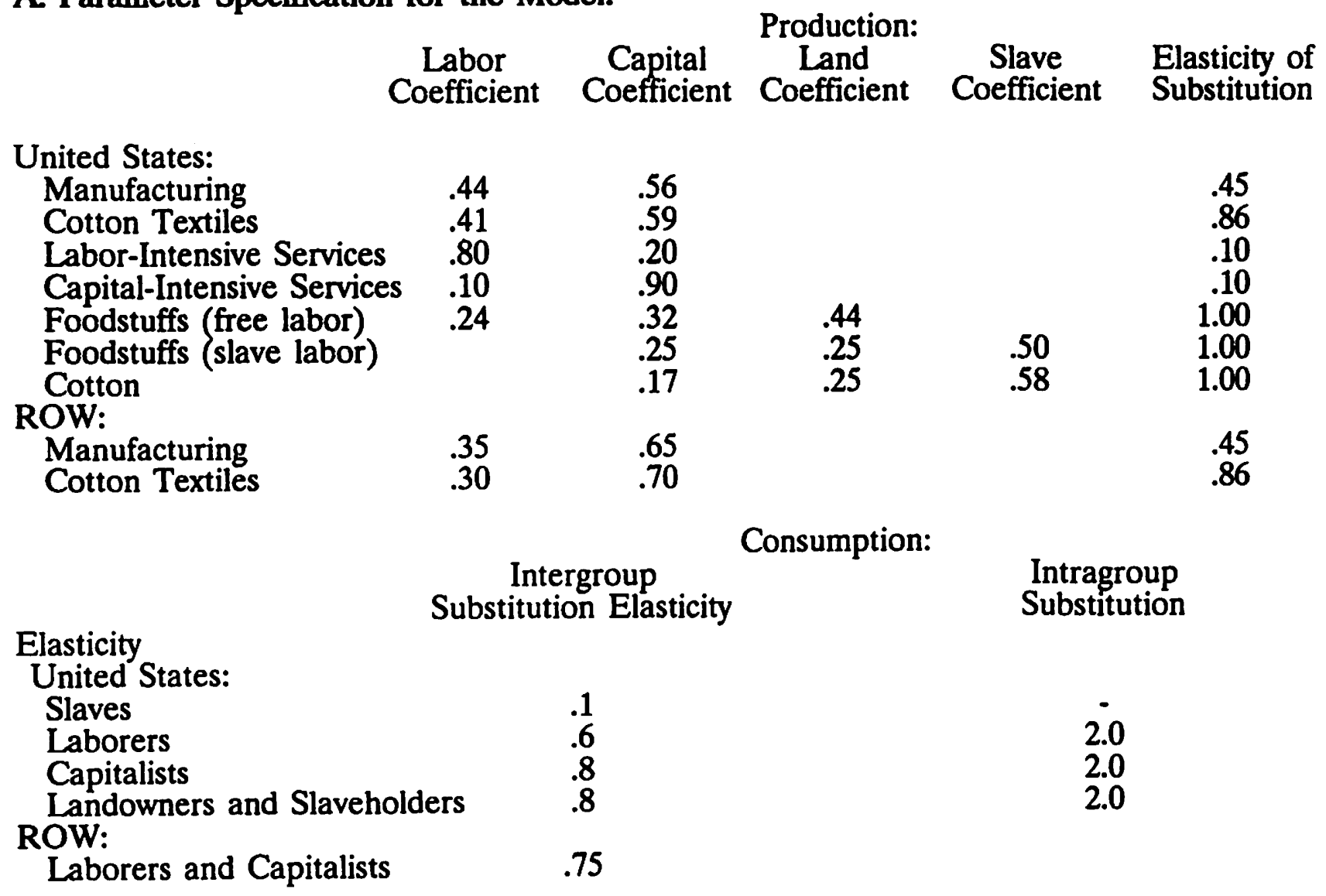

B. Benchmark U.S. Economy in 1859 (\$ million):

Gross National Product:

Value-Added:

Factor Income:

Manufacturers

Cotton Textiles

Foodstuffs

Cotton

Labor-Intensive Services

Capital-Intensive Services

Total

Exports:

Foodstuffs

Cotton

Total

Tariff revenues:
814.1

58.4

1246.5

248.5

1095.0

654.0

4116.5
Labor

Capital

Land

Slaves

Total

Balance of Trade:
1628.90

1730.63

612.84

144.13

4116.50

Imports:

Manufacturers

244.2

Cotton Textiles

16.0

Total 


\section{Table 2}

Price and Quantity Changes for Traded Goods

A. James' Results (1978, p. 248):

Benchmark with tariff with tariff removed

Price Quantity traded Price Quantity traded

U. S. Exports:

Raw cotton

1.00

175

1.07

188

Food

1.00

85

1.00

117

U. S. Imports:

Cotton Textiles

1.00

16

1.14

18

Other Manufactures 1.00

244

1.14

262

B. Re-estimation:

Benchmark James' Specification Big Rest of World Price Quantity Price Quantity Price Quantity

U. S. Exports:

Raw cotton

$1.00 \quad 190$

$1.07 \quad 203$

$1.01 \quad 192$

Food

$1.00 \quad 70$

1.00

84

$1.00 \quad 148$

U. S. Imports:

Cotton Textiles

$1.00 \quad 16$

1.17

18

1.01

23

Other Manufactures 1.00 
Table 3

Alternative Specifications for General Equilibrium Modelling

Case Specification

EXTREME CASES:
A. (James)
James' specification (see Table 1)
B. (Big R.o.W)
Respecified rest of the world
1. Increased size and diversified.
Foreign food production:
$\$ 12500$
Foreign cotton textiles:
525
Foreign other manufacture:
7000
Foreign services:
10000

2. Foreign cotton production with an elasticity of transformation of 0.8 with food production.

3. CES subaggregate of cotton textiles and other manufacture with an elasticity of substitution of 1.5 . C.(Perfect Sub.) As Case B, except imported and domestic cotton textiles and
other manufactures are prefect substitutes.

PLAUSIBLE CASES:

I. (Low Sub.) As Case B, except that the elasticity of substitution between imported and domestic cotton textiles is increased to 10 and between imported and domestic other manufactures to 5 .

II. (High Sub.) As Case B, except that imported and domestic cotton textiles are perfect substitutes and the elasticity between imported and domestic other manufactures is increased to 5 .

III.(Immobile L.I) As Case I, except that labor is not perfectly transferable between sectors but is transformed with an elasticity of 5 .

IV.(Immobile L.II) As Case II, except that labor is not perfectly transferable between sectors but is transformed with an elasticity of 5 . 
Table 4

Results of Various Simulations of Tariff Removal

Plausible Cases: $\quad$ Extreme Cases:

$\begin{array}{lllllll}\text { Benchmark I } & \text { II } & \text { III } & \text { IV } & \text { B } & \text { C }\end{array}$

Quantities:

U.S. cotton textiles:

U.S. other manufactures:

$\begin{array}{lllllll}117 & 66 & 0 & 76 & 4 & 111 & 0\end{array}$

$\begin{array}{rrrrrrr}814 & 674 & 566 & 700 & 635 & 764 & 0\end{array}$

U.S. food production:

1246

1409

1533

1385

1409

$1301 \quad 1995$

U.S. cotton production:

248

244

240

246

242

$247 \quad 234$

U.S. non traded services:

1749

Cotton textile imports:

Other man. imports:

Food exports:

Raw cotton exports:

$\begin{array}{rrrrrrr}16 & 65 & 123 & 57 & 120 & 23 & 119 \\ 244 & 405 & 506 & 387 & 451 & 319 & 980 \\ 70 & 258 & 390 & 235 & 333 & 148 & 877 \\ 190 & 211 & 240 & 208 & 240 & 192 & 234\end{array}$

Prices (U.S. food = numeraire):

U.S. cotton textiles:

100

Imported cotton textiles:

U.S. other manufactures:

Imported other man.:

Raw cotton:

U.S. non traded services:

U.S. Terms of trade:

$\begin{array}{lllllll}100 & 81 & 82 & 81 & 81 & 81 & 83\end{array}$

$\begin{array}{lllllll}100 & 96 & 94 & 95 & 91 & 98 & 85\end{array}$

$\begin{array}{lllllll}100 & 84 & 84 & 84 & 84 & 83 & 85\end{array}$

$\begin{array}{lllllll}100 & 101 & 101 & 101 & 101 & 101 & 105\end{array}$

$\begin{array}{lllllll}100 & 97 & 94 & 97 & 95 & 99 & 87\end{array}$

$\begin{array}{lllllll}100 & 101 & 100 & 101 & 100 & 102 & 102\end{array}$

U.S. factor prices:

Labor:

100

Cotton:

100

Manufacturing:

Other:

100

100

Capital:

100

100

Land:

Slaves:

100

$\begin{array}{rrrrrr}98 & 97 & 98 & 96 & 99 & 93 \\ & & 90 & 50 & & \\ & & 95 & 92 & & \\ & & 99 & 98 & & \\ 94 & 90 & 94 & 91 & 98 & 77 \\ 111 & 119 & 109 & 115 & 104 & 150 \\ 100 & .98 & 100 & 98 & 100 & 99\end{array}$

U.S. utility levels:

Labor:

$\begin{array}{rrrrrrr}1.000 & 1.005 & 1.012 & 1.004 & 1.009 & 1.002 & 1.023 \\ 1.000 & .966 & .944 & .970 & .953 & .987 & .841 \\ 1.000 & 1.138 & 1.245 & 1.123 & 1.201 & 1.053 & 1.644 \\ 1.000 & 1.021 & 1.021 & 1.025 & 1.019 & 1.012 & 1.073 \\ 1.000 & 1.005 & 1.011 & 1.004 & 1.008 & 1.002 & 1.021\end{array}$

Capital:

Land:

Slave owners:

1.000

Aggregate: 
Table 5

Effect of Relative Prices Changes on Consumption Shares

Various Elasticities of Substitution

Benchmark Shares of Sales when Price of Imported Shares

Goods Falls by the Amount of the Tariff.

Elasticities:

2

5

10

Cotton Textiles:

Domestic

.85

.15

.83

.17

.71

.29

.46

Imports.

Manufactures:

Domestic

.73

Imports

.27

.70

.57

$.30 \quad .43$

.35

.65 
Table 6

Canadian Imports from Britain and the United States, 1857

(thousands $\mathfrak{f}$ )

Great Britain United States Total

I. Specific Items:

Textiles:

Cotton

Wool

Linen

Silk

1102

Leather:

Shoes and boots

Other manufactures

Iron and Steel

Hardware

Machinery

II. Summary Statistics:

Goods paying specific duty (Sugar, tea, spirits, etc)

Goods paying ad valorem duty (mainly manufactures)

Free goods

(mainly raw materials)

Total
857

75

236

91

77

8

11

77

584

64

244

240

16

69
81
52

81
52

652

490

86

1199

943

84

256

86


Table 7

Percentage Change in Welfare with Tariff Removal, Various Groups

$\begin{array}{lllll}\text { Case: } & \text { I } & \text { II } & \text { III } & \text { IV }\end{array}$

I. Social Group:

Capital

$-3.4 \quad-5.6$

$-3.0$

$-4.7$

Land

13.8

24.5

12.3

20.1

Slave owners

2.1

2.1

2.5

1.9

Labor:

Aggregate

0.5

1.2

0.4

0.9

Cotton textile

$-6.0$

$-15.1$

Other manufacturing

$-2.3$

$-4.1$

Other sectors

1.3

2.3

Farmers:

Capital owners

Debtors

2.9

5.2

3.0

5.0

4.9

9.9

4.9

9.2

Planters

$\begin{array}{ll}4.1 & 6.3\end{array}$

4.0

5.3

II. Regional Non-farm Labor Aggregations:

New England

$-0.5$

$-1.0$

Mid Atlantic

West

$-0.4$

$-0.4$

South

0.5

1.2

0.7

1.4

III. Regional Aggregations:

A. All regional capital locally owned:

East

West

South

0.0

0.8

1.2

B. Half of western capital owned in east:
$-0.1$

1.5
0.0

1.5

2.2

$-0.1$

3.0
$-0.1$

0.9

1.4

0.0

1.7

2.2

$-0.1$ 2.9 
Notes

1. Taussig concluded (1931, p. 152) that "[t]he extent to which mechanical branches of production have been brought into existence by the protective system has been greatly exaggerated" and (p. 136) that "almost certainly by 1832 , the [cotton] industry...was able to meet foreign competition on equal terms." Recent economic historians concur: Copeland (1917, Ch. 1), Stettler (1970), Zevin (1972), Fogel and Engerman (1969). Trade economist's theory of optimal tariffs has reinforced this view. Because antebellum America possessed market power in raw cotton, restricting its output would have increased its price to America's benefit. In simple two goods models, benefits could be captured by either an export tax or an import tariff. Within this theoretical framework, as Lloyd Metzler (1949) pointed out, market power could have been so great that the tariff moved U. S. domestic prices adversely for manufacturing, hurting American manufacturing and benefitting the South. Metzler concluded (1949, p. 27) "the net effect of protection during this period may even have been slightly adverse to manufacturing as a whole."

2. This issue has emerged repeatedly in applied general equilibrium models. The goods in these models represent aggregations whose components differ with respect to tradability and location of comparative advantage. The usual solution, adopted by James, is a socalled Armington specification for the utility function in which imports and exports of each category are aggregated with less than perfect substitution to form a composite good that them enters into a higher level utility function (see Dervis et. al. (1982, pp. 221-224) and Shoven and Whalley (1984, pp. 1017, 1034 and 1042).

3. I am extremely grateful to my colleague Thomas F. Rutherford who has made his 
MPS/GE software (Rutherford, 1988) available to me and provided extensive assistance in its use. This work would almost certainly not have been undertaken without his program.

4. Changes in cotton price and quantity are virtually identical but manufacturing results are somewhat different. My simulation with James' specification has a Metzler effect. American imports of other manufactures fell with tariff removal and American production of competing goods rose. Changes in cotton textiles are somewhat larger than his, domestic price actually rises somewhat in response to higher cotton price, but quantity falls by just over five percent in contrast to James' two percent. Factor price and welfare changes are very similar.

5. The underlying model indicates the smooth results are appropriate. In the model, the rest of the world is entirely dependant on the American economy for raw cotton and food. Demand is generated by a CES utility function with an elasticity of substitution of 0.8 . Consequently these commodities will always be demanded inelastically and a monopoly seller always benefits from restricting supply.

6. James does not report export quantities but they can be calculated quite easily. Cotton exports are cotton production (reported) less domestic consumption. Cotton enters the cotton textile production function with fixed proportions so domestic demand can be calculated from textile output. The quantity of food can be calculated from the balance of payments constraint and the reported price of food.

7. In Clayne Pope's local approximation of a general equilibrium model of the antebellum tariff, food is assumed to be non-traded and cotton is the only export good (1975, p. 48). 
8. The manufacturing sectors are based on Ellison (1886, p. 100) and Bairoch (1982, p. 275). Food production is roughly based on population. McEvedy and Jones (1978, pp. 18, 287) place the population of Europe in 1850 at 265 million and that of the U. S. at 24 million. James uses $\$ 124.65$ for U.S. food output excluding slave production. I have set the rest of the world at 1250 , in round numbers ten times that of the U.S. roughly reflecting population (in some simulations I have halved this quantity without substantially altering the results). A service sector is half the sum of the output of the commodity producing sectors.

9. That is to say American food and Rest of the World food are considered the same good in the consumption of the rest of the world. The price of food can change relative to other goods in the model in response to general equilibrium forces.

10. The magnitudes of the adjustments are very sensitive to the specification of American demand for imports, see the simulations (Table 4 and discussed below). Even the largest increase in food exports (in Case 3, 12.5 times the benchmark level) seems plausible in light of the enormous expansion of agricultural output and exports in the two decades after 1860 .

11. At tariff rates above about thirty percent (the welfare minimum points in Figure 1), U. S. food exports disappear and the market power of cotton comes into play.

12. An export tax results in lower raw cotton costs to the American cotton textile industry than to its foreign competitors. This is no problem if the U.S. industry does not export. Figure 2 has been calculated on this assumption. In the optimal tax equilibrium, however, the price of foreign cotton textiles have risen to some four percent above the benchmark 
U.S. price implying that the U.S. industry would export. Exports of untaxed cotton textiles would have attenuated the gains from the export tax. First, reduced foreign demand for raw cotton would reduced the terms of trade effect. Second, increasing U.S. cotton textile production would reduce efficiency. The optimal export tax would, therefore, have been somewhat lower, probably in the range on forty to fifty percent.

13. See Temin (1988), p. 897 - 8.

14. This sort of large "terms of trade" effects where tariff removal increases the price of domestic production relative to imports is a common feature of models with Armington specifications and has generated some concern (Shoven and Whalley, 1984, p. 1042). Even for modern studies evidence on appropriate values for these Armington elasticities is quite poor (Shiells, et. al., 1986).

15. For details of the argument briefly presented below see Harley (1992).

16. Rutherford's (1988) MPS/GE model does not allow values in excess of 10. Greater substitutability has been explored by considering imports and American textiles perfect substitutes.

17. Fogel and Engerman (1969) suggest a somewhat different conclusion. Their conclusion rests heavily on poor substitution of imports for domestic production in consumption.

18. Experiments indicate that a change in cotton textile prices of a little over one percent relative to other domestic prices is sufficient to draw all resources from that industry. The 
supply to manufacturing in general is less elastic than that to cotton, due to its larger size, but remains very high.

19. Distributional effects of the simulations are discussed in detail in Section IV below. 


\section{REFERENCES}

Allen, Robert (1979), "International Competition in Iron and Steel, 1850 -1913." Journal of Economic History 39, 911 - 937.

Baack, Bennett and Edward Ray (1973/74), "Tariff Policy and Income Distribution: The Case of the United States 1830 - 1860." Explorations in Economic History 11, 103 121.

Bairoch, Paul (1982), "International Industrialization Levels from 1750 to 1980." Journal of European Economic History 11, 269 - 334.

Bils, Mark (1984), "Tariff Protection and Production in the Early U.S. Cotton Textile Industry." Joumal of Economic History 44, 1033 -1046.

Copeland, Melvin T. (1917), The Cotton Manufacturing Industry of the United States. Cambridge, Mass.: Harvard University Press.

Dervis, K, J. de Melo, and S. Robinson (1982), General Equilibrium Models for Development Policy. Cambridge: Cambridge University Press.

Ellison, Thomas (1886), The Cotton Trade of Great Britain. Reprint New York: Agustus M. Kelley, 1968.

Field, Alexander (1978), "Sectoral Shifts in Antebellum Massachusetts." Explorations in Economic History 15, 146 - 171.

Fogel, Robert and Stanley Engerman (1969), "A Model for the Explanation of Industrial Expansion during the 19th. Century: With Application to the American Iron Industry." The Journal of Political Economy 77, 306 - 328.

Goldin, Claudia, and Kenneth Sokoloff (1982), "Women, Children, and Industrialization in the Early Republic." Journal of Economic History 42, 741 - 774.

James, John (1978), "The Welfare Effects of the Antebellum Tariff: A General Equilibrium Analysis." Explorations in Economic History 15, 231 -256.

James, John (1981), "The Optimal Tariff in Antebellum United States." American Economic Review 71, 726 - 734.

Harley, C. Knick (1980), "Transportation, the World Wheat Trade and the Kuznets Cycle, 1850 - 1913." Explorations in Economic History 17, 218 - 250. 
Harley, C. Knick (1982), "British Industrialization Before 1841: Evidence of Slower Growth During the Industrial Revolution." Joumal of Economic History 42, 267 - 289.

Harley, C. Knick (1992), "International Competitiveness of the Antebellum American Cotton Textile Industry." Joumal of Economic History.

McEvedy, Colin and Richard Jones (1978), Atlas of World Population History. Harmondswoth, Middlesex: Penguin.

Metzler, Lloyd (1949), "Tariffs, the Terms of Trade, and the Distribution of National Income." The Journal of Political Economy 57, 1 - 29.

Neimi, Albert W., Jr. (1974), State and regional Patterns in American Manufacturing, 1860 1900. Westwood, Conn.: Greenwood Press.

Pope, Clayne (1972), "The Impact of the Antebellum Tariff on Distribution." Explorations in Economic History 9, 375 - 421.

Pope, Clayne (1975), The Impact of the Ante-Bellum Tariff on Income Distribution. New York: Arno Press.

Robinson, Sherman (1989), "Multisectoral Models." In H. Chenery and T.N. Srinivasan, eds., Handbook of Development Economics, Volume II. Amsterdam: Elsevier Science Publishers B. V., 885 - 947.

Rutherford, Thomas (1988), "General Equilibrium Modelling with MPS/GE." Unpublished manuscript, Department of Economics, University of Western Ontario.

Shiells, Clinton R., Robert M. Stern, and Alan V. Deardorff (1986), "Estimates of the Elasticities of Substitution between Imports and Home Goods for the United States." Weltwirtschafliches Archiv 122, 497 - 519.

Shoven, J. B., and J. Whalley (1984), "Applied General Equilibrium Models of Taxation and International Trade." Journal of Economic Literature 22, 1007 - 1051.

Stettler, Henry Louis III (1970), "Growth and Fluctuations in the Ante-bellum Textile Industry." Unpublished Ph. D. Thesis, Purdue University.

Taussig, F. W. (1931), Tariff History of the United States. New York: G. P. Putnam's Sons.

Temin, Peter (1988). "Product Quality and Vertical Integration in the Early Cotton Textile Industry." Journal of Economic History 48, 891 - 907. 
Whalley, John (1992), "General Equilibrium Trade Modelling over the Last Five Years." In J. B. Shoven and J. Whalley, eds., Applied General Equilibrium II. Cambridge: Cambridge University Press.

Zevin, Robert (1972), "The Growth of Cotton Production after 1815." In Robert Fogel and Stanley Engerman (eds.), The Reinterpretation of American Economic History. New York: Harper and Row. 
Figure 1

Welfare and Tariff Rates

Various Specifications

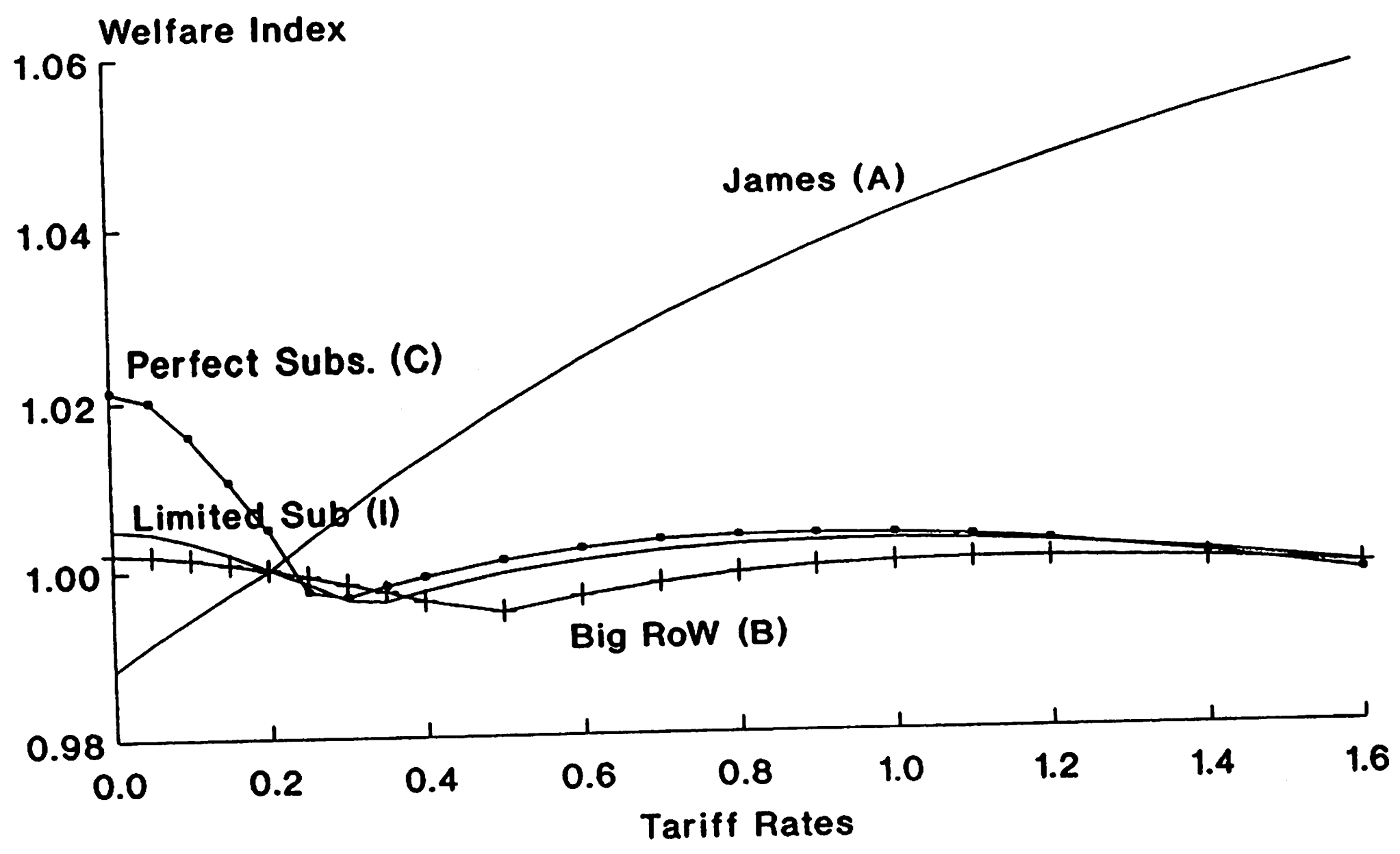

Note: Welfare index $=1.00$ at 1859 benchmark 
Figure 2

Cotton Export Tax and Welfare

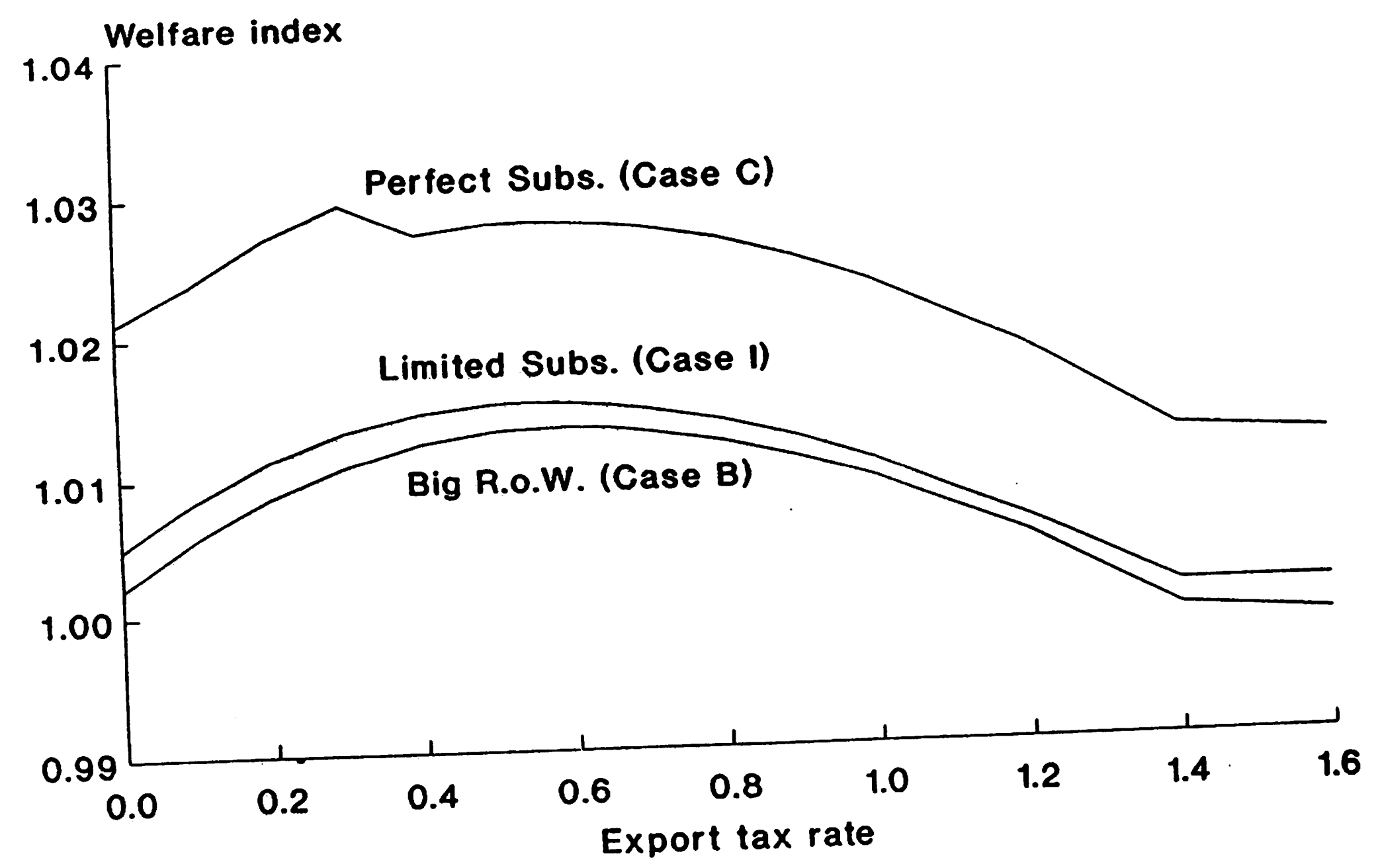

Note: Welfare index -1.00 at 1859 benchmark 
Figure 3

U. S. Tariff, $1821-1860$

A. Ratio of Duty to Dutiable Imports

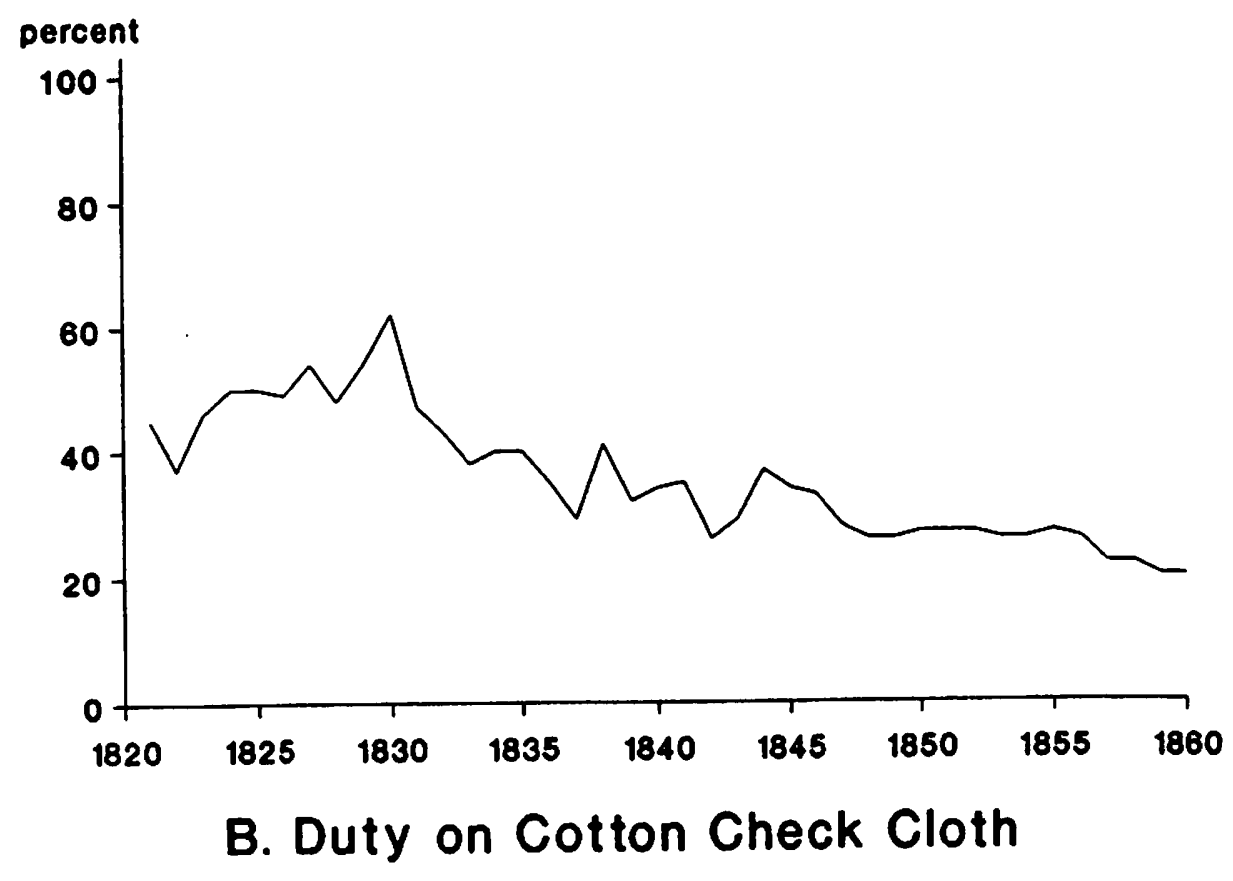

percent

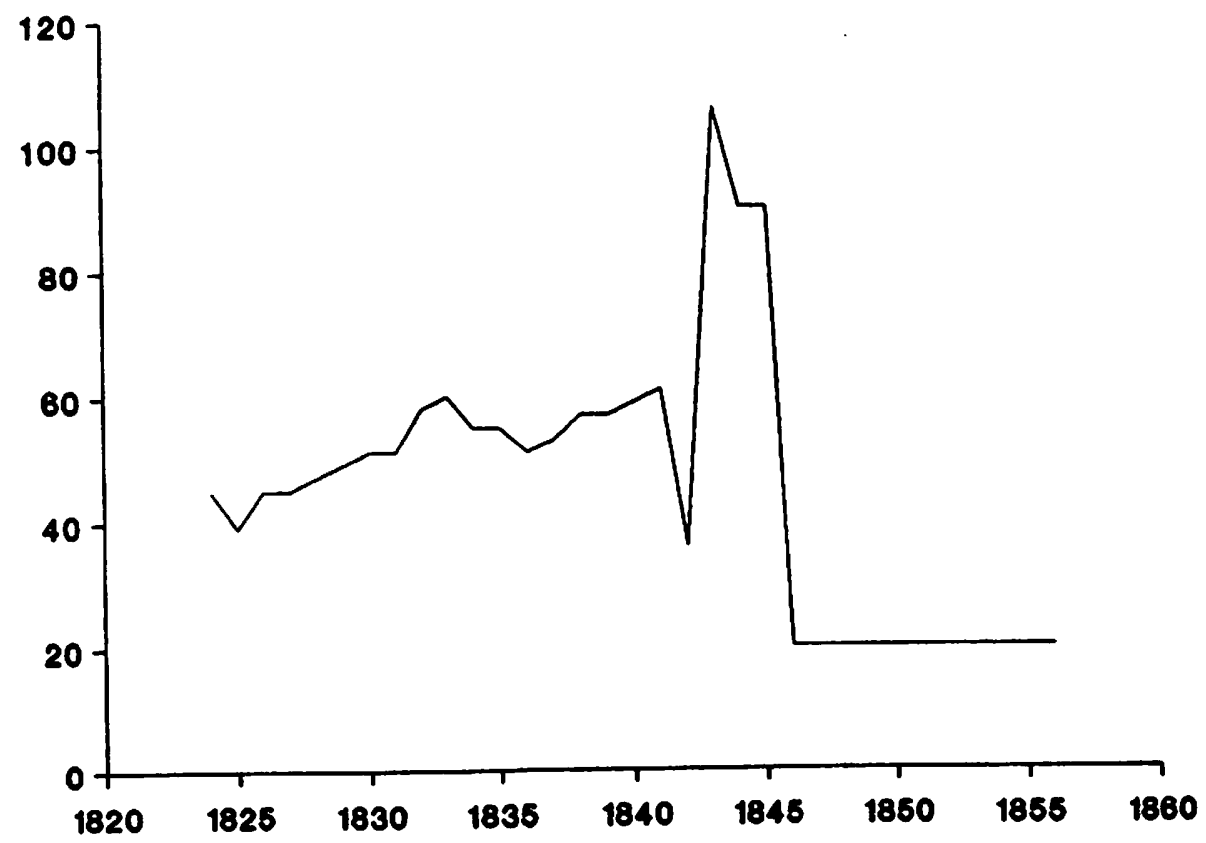


Figure 4

\section{Relative Wage and Labor Transfer}

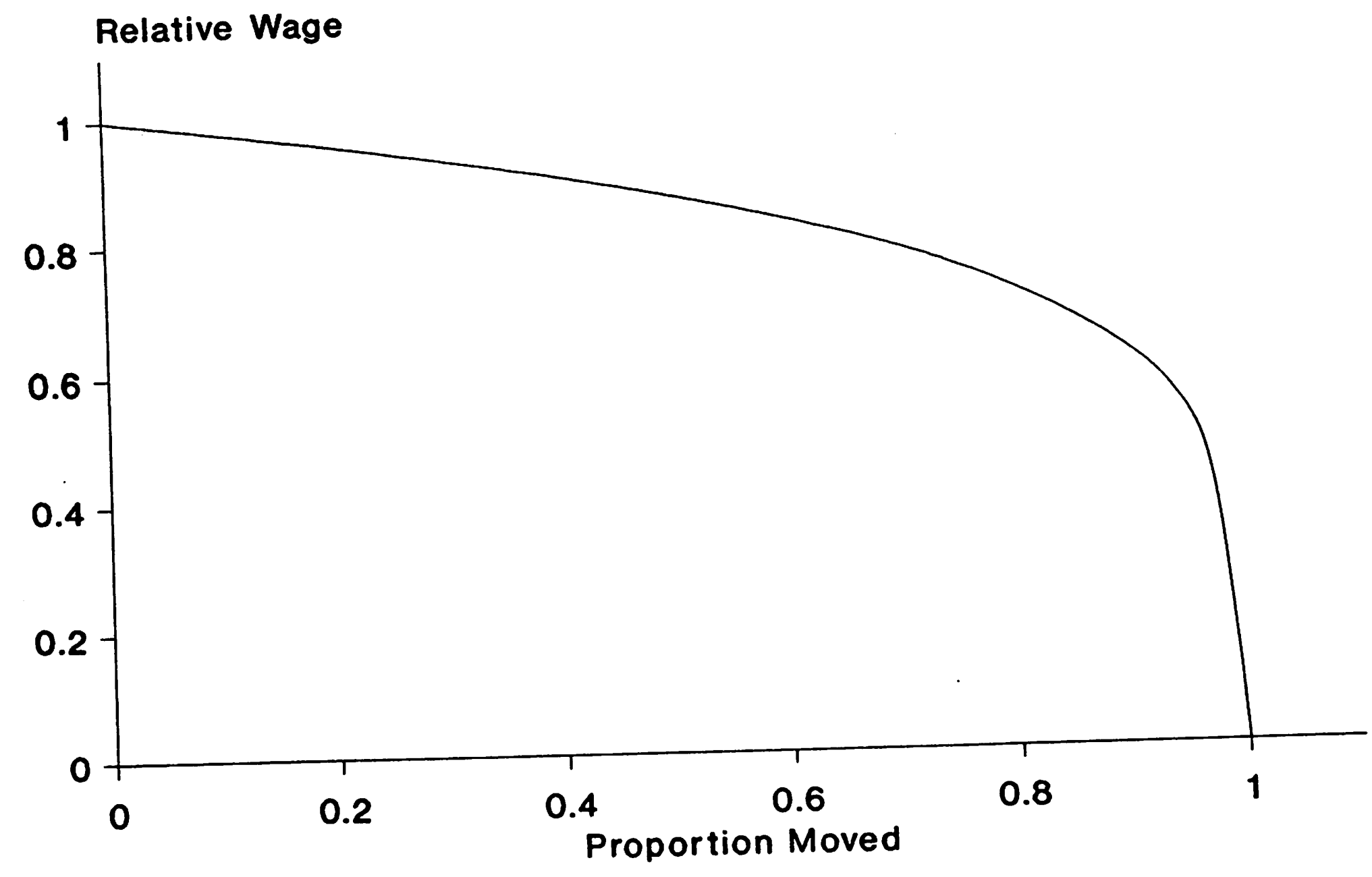

Source: Calculated from CES with transformation elast. - 5.0 